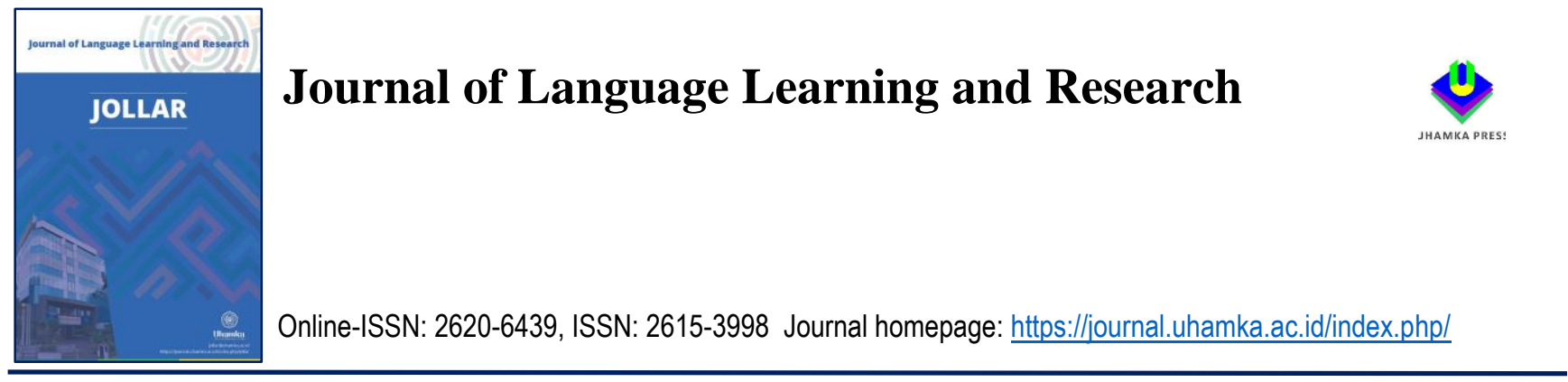

\title{
Examining the Effectiveness of Folktale in Enhancing Students' Listening Comprehension on Narrative Story
}

Tri Ilma

How to cite : Ilma,T. 2020. Examining the Effectiveness of Folktale in Enhancing Students' Listening Comprehension on Narrative Story. Journal of Language Learning and Research. 3(1). 30-39. https://doi.org/10.22236/jollar.v3i1.5379

To link to this article: https://doi.org/10.22236/jollar.v3i1.5379

\section{(2) Opened Access Article๘}

曲 Published Online on 11 Maret 2020

怔 Submit your paper to this journal

View Crossmark data 


\title{
Examining the Effectiveness of Folktale in Enhancing Students' Listening Comprehension on Narrative Story
}

\author{
Tri Illma Septiana $\otimes^{1}$
}

Received: 20 Desember 2020 Accepted: 6 Maret 2021 Published: 11 Maret 2021

\begin{abstract}
Listening does not receive special attention in teaching and learning processes of English at the Eleventh Grade of MAN 8 Jakarta. This is caused by English teacher's misconception that speaking and writing should be put in the first priority because they are considered as productive skills. Meanwhile, listening is classified into respective skill. In teacher's view, productive skills is often valued batter than receptive skill. Consequently, some students do not have good listening comprehension. In principal, this study was conducted to examine the effectiveness of folktale in enhancing students' listening comprehension on narrative story. Moreover, due to this study utilized experimental method, so two classes were involved. They were XI IPA 1 acted as experimental group and XI IPA II acted as control group. In addition, to obtain valid data, sixty students from both groups were selected randomly to join pre-test and post-test with similar listening test items. The findings of this study showed that the mean score of post-test for experimental group was 80.8 and 68.53 for control group with the degree of freedom (df) was 58 . However, the value of $t_{0}$ ( $t$-count) was 5.96 and the value of $t_{t}$ (t-table) on degree of significance of 5\% was 1.67. Having obtained the data, the researcher compared $t_{0}$ to $t_{t}$ and the result showed that $t_{0}>t_{t}=5.96$ $>1.67$. It indicates that that $\mathrm{H}_{1}$ or alternative hypothesis was accepted. In other words, This study pointed out that there was significant effect of folktale in enhancing students' listening comprehension on narrative story.
\end{abstract}

Keywords: listening, folktale, narrative storyt, experimental study.

\section{INTRODUCTION}

Inevitably, for many years before the emergence of communicative approach, listening skills did not receive priority in language teaching. Teaching English more emphasized productive skills and relationship between productive and receptive skills was poorly understood. Nunan (2002:238) reveals that listening is the Cinderella skill in second language learning. All too often, it has been overlooked by its elder sister - speaking. For most people, being able to claim knowledge of a second language means being able to speak and write in that language. However, currently, listening plays a more a central role in language teaching. Some examinations such as university entrance exams, school leaving tests, TOEFL, TOEIC, and IELTS have begun to include a listening component, this is an acknowledgment that listening ability is an important aspect of second language proficiency (Flowerdew and Miller, 2005).

\footnotetext{
$\triangle$ Tri Ilma Septiana

tri.ilma@uinbanten.ac.id

${ }^{1}$ UIN Sultan Maulana Hasanuddin Banten, Indonesia
} 
As matter of fact, in teaching and learning processes of English, listening is often neglected by some English teachers without exception in MAN 8 Jakarta. Based on my preliminary study, I found some students still have difficulties in listening. Those problems can be elaborated are as follows: First, some students lack of listening exposure and less listening practice in teaching and learning processes. From classroom observation, I saw teacher seldom taught listening and she more frequent to emphasize English lesson on grammar and vocabulary mastery, fluently in speaking and comprehension in reading. Second, teacher thought that speaking, writing, vocabulary, grammar were valued better than listening. It reflects on formative or summative test which did not include listening as one of test component. Third, teacher lacks of listening materials. In an interview, the English teacher admitted that she only used student worksheet as learning source and seldom invited students to language laboratory for learning listening. Fourth, some students lack vocabularies mastery, lack knowledge in variations of accents and dialects, as well as unfamiliar with topic. Those factors contributed significant influence on students' difficulties in learning listening. Fifth, teacher never taught some best practice of listening. Besides, she was often incorrect in selecting listening material for students.

Naturally, listening is different to hearing (Nunan, 2002; Buck, 2003; Flowerdew and Miller, 2005; Brown, 2006). In general, hearing is physiological process of ears absorbing sound waves and transferring them along neural pathways to parts of the brain. Meanwhile, listening is more than processing sound, it is a complex process in which the listeners' take the incoming data, an acoustic signal, and interpret it based on wide variety of linguistic and non-linguistic knowledge. The linguistic knowledge includes knowledge of phonology, lexis, syntax, semantics, discourse structure, pragmatics, and sociolinguistics. Otherwise, the non-linguistic knowledge includes knowledge of topic, the context and general knowledge about world, and how it works.

Principally, helping students to listen with understanding is much easier if they are motivated and actively engaged while listening. It must be remembered that listening is not passive activity. Learning listening through folktale can develop student's basic skill (e.g. speaking, writing, listening, and reading), comprehension (grammar), enrich vocabularies mastery and general knowledge, and build selfconfidence (Ellis and Brewster, 1991:1-2). Besides, folktale also provokes a shared response of laughter, sadness, and excitement. It can also help build up students' confidence, drill imagination and fantasy, encourage social and emotional development, as well as develop their concentration skill via visual clues (e.g. pictures and illustration), prior knowledge of how language works, and general knowledge.

\section{METHODOLOGY}

Due to this study want to examine the effectiveness of folktale in enhancing students' listening on narrative story, so experimental study will be employed as research method because experimental study will compare behavior in two groups of participants who have been randomly selected and assigned to control and treatment groups and then given control and experimental treatments (Brown and Rodgers, 2003:211). Moreover, to cope with students' problems in learning listening and to examine the effectiveness of folktale. The research design of this study can be illustrated as follows 


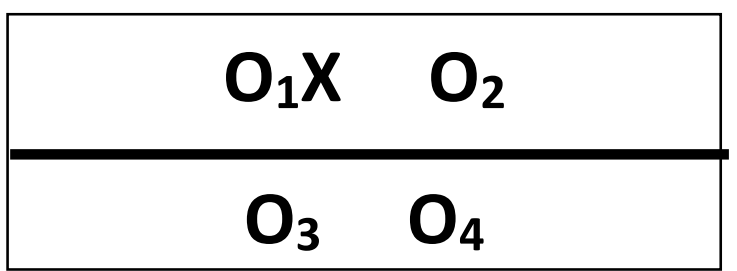

Where:

$\mathrm{O}_{1} \quad$ : Experimental group before given treatment

$\mathrm{O}_{3}:$ Control group

$\mathrm{X}:$ : Treatments

$\mathrm{O}_{2} \quad$ : Experimental group after given treatment

$\mathrm{O}_{4} \quad$ : Control group without given (Fraenkel and Wallen, 2007:271)

Having given post-test to both groups, then data of post-test for experimental group will be coded variable XI and X2 for control group. Then, the next steps of analyzing data for experimental study are as follows:

1. Calculating students' listening score by using formula as follows:

Student Score $=\frac{\text { Student's right answer }}{\text { Total Items }} \times 100$

2. Determining mean of variable $\mathrm{X} 1$ with formula as follows:

$M_{1}=\frac{\sum X_{1}}{N_{1}}$

3. Determining mean of variable $\mathrm{X} 2$ with formula as follows:

$M_{2}=\frac{\sum X_{2}}{N_{2}}$

4. Counting standard of deviation score variable $\mathrm{X} 1$ with formula as follows:

$\mathrm{X}_{1}=\mathrm{X}_{1}-\mathrm{M}_{1}$

5. Counting standard of deviation score variable $\mathrm{X} 1$ with formula as follows:

$\mathrm{X}_{2}=\mathrm{X}_{2}-\mathrm{M}_{2}$

6. Testing normality of data by using Lilliefors method with formula as follows:

$Z=\frac{X-\bar{X}}{S D}$

7. Counting degree of freedom with formula as follows:

$\mathrm{df}=\mathrm{N} 1+\mathrm{N} 2-2$

8. Analyzing and comparing the result of post-test from both groups by using t-test formula as follows:

$$
t_{0}=\frac{M_{1}-M_{2}}{\sqrt{\left\{\frac{\sum X_{1}^{2}+\sum X_{2}^{2}}{N_{2}+N_{2}-2}\right\}\left\{\frac{N_{1}+N_{2}}{N_{1} \cdot N_{2}}\right\}}}
$$

\section{FINDINGS AND DISCUSSION}

Having computed listening score of post-test from both classes. Then, the data were first should be tested statistically by using the normality test. Normality test as a perquisite test of t-test is used to show that the data sample come from population which have normal distribution (Darwiansyah, 2006). In this study, I used Lilliefors method to test data distribution of post-test from experimental and control group. 
In the following lines will be shown the results of normality test from both classes. Initially, I calculated standard deviation of both classes, the results will be provided alternately:

Table 1 the Post-test Result of Experimental Group

\begin{tabular}{ccccccc}
\hline Respondent & $\mathbf{X}$ & $\mathbf{F}$ & $\mathbf{F X}$ & $\mathbf{X 1}$ & $\mathbf{X}^{\mathbf{2}}$ & $\mathbf{F X}^{\mathbf{2}}$ \\
\hline $\mathbf{1}$ & 64 & 1 & 64 & -16.8 & 282.24 & 282.24 \\
\hline $\mathbf{2}$ & 68 & 1 & 68 & -12.8 & 163.84 & 163.84 \\
\hline $\mathbf{3}$ & 72 & 3 & 216 & -8.8 & 77.44 & 232.32 \\
\hline $\mathbf{4}$ & 76 & 6 & 456 & -4.8 & 23.04 & 138.24 \\
\hline $\mathbf{5}$ & 80 & 6 & 480 & -0.8 & 0.64 & 3.84 \\
\hline $\mathbf{6}$ & 84 & 6 & 504 & 3.2 & 10.24 & 61.44 \\
\hline $\mathbf{7}$ & 88 & 3 & 264 & 7.2 & 51.84 & 155.52 \\
\hline $\mathbf{8}$ & 92 & 3 & 276 & 11.2 & 125.44 & 376.32 \\
\hline $\mathbf{9}$ & 96 & 1 & 96 & 15.2 & 231.04 & 231.04 \\
\hline & Total & 30 & 2424 & & & 1644.8 \\
\hline & $\boldsymbol{\mu}$ & & 80.8 & & & \\
\hline & SD & & 7.4 & & & \\
\hline
\end{tabular}

Determining mean of experiment group (X1) by using formula as follows:

$\bar{X}=\frac{\sum F X}{\sum F}$

$\bar{X}=\frac{2424}{30}=80.8$

Counting standard deviation of experimental group (X1) by using formula as follows:

$S D=\sqrt{\frac{\sum F X}{\sum F}}$
$S D=\sqrt{\frac{1644.8}{30}}$
$S D=\sqrt{54.82}=7.4$

Furthermore, the previous data are used to test its normality by using Lilliefors formula as follows:

Table 2 Normality Test of Experiment Group

\begin{tabular}{cccccc}
\hline No & $\mathbf{X 1}$ & $\mathbf{Z}$ & $\mathbf{F}(\mathbf{Z})$ & $\mathbf{S}(\mathbf{Z})$ & $(\mathbf{F}(\mathbf{Z})-\mathbf{S}(\mathbf{Z}))$ \\
\hline $\mathbf{1}$ & 64 & -2.27 & 0.0116 & 0.03 & 0.0184 \\
\hline $\mathbf{2}$ & 68 & -1.72 & 0.0427 & 0.06 & 0.0173 \\
\hline $\mathbf{3}$ & 72 & -1.18 & 0.119 & 0.1 & 0.019 \\
\hline $\mathbf{4}$ & 72 & -1.18 & 0.119 & 0.13 & 0.011 \\
\hline $\mathbf{5}$ & 72 & -1.18 & 0.119 & 0.16 & 0.041 \\
\hline $\mathbf{6}$ & 76 & -0.64 & 0.2611 & 0.2 & 0.0611 \\
\hline $\mathbf{7}$ & 76 & -0.64 & 0.2611 & 0.23 & 0.0311 \\
\hline
\end{tabular}




\begin{tabular}{cccccc}
\hline $\mathbf{8}$ & 76 & -0.64 & 0.2611 & 0.26 & 0.0011 \\
\hline $\mathbf{9}$ & 76 & -0.64 & 0.2611 & 0.3 & 0.0389 \\
\hline $\mathbf{1 0}$ & 76 & -0.64 & 0.2611 & 0.33 & 0.0689 \\
\hline $\mathbf{1 1}$ & 76 & -0.64 & 0.2611 & 0.36 & 0.0989 \\
\hline $\mathbf{1 2}$ & 80 & -0.1 & 0.4602 & 0.4 & 0.0602 \\
\hline $\mathbf{1 3}$ & 80 & -0.1 & 0.4602 & 0.43 & 0.0302 \\
\hline $\mathbf{1 4}$ & 80 & -0.1 & 0.4602 & 0.46 & 0.0002 \\
\hline $\mathbf{1 5}$ & 80 & -0.1 & 0.4602 & 0.5 & 0.0398 \\
\hline $\mathbf{1 6}$ & 80 & -0.1 & 0.4602 & 0.53 & 0.0698 \\
\hline $\mathbf{1 7}$ & 80 & -0.1 & 0.4602 & 0.56 & 0.0998 \\
\hline $\mathbf{1 8}$ & 84 & 0.43 & 0.3336 & 0.6 & 0.2664 \\
\hline $\mathbf{1 9}$ & 84 & 0.43 & 0.3336 & 0.63 & 0.2964 \\
\hline $\mathbf{2 0}$ & 84 & 0.43 & 0.3336 & 0.66 & 0.3264 \\
\hline $\mathbf{2 1}$ & 84 & 0.43 & 0.3336 & 0.7 & 0.3664 \\
\hline $\mathbf{2 2}$ & 84 & 0.43 & 0.3336 & 0.73 & 0.3964 \\
\hline $\mathbf{2 3}$ & 84 & 0.43 & 0.3336 & 0.76 & 0.4264 \\
\hline $\mathbf{2 4}$ & 88 & 0.97 & 0.166 & 0.8 & 0.634 \\
\hline $\mathbf{2 5}$ & 88 & 0.97 & 0.166 & 0.83 & 0.664 \\
\hline $\mathbf{2 6}$ & 88 & 0.97 & 0.166 & 0.86 & 0.694 \\
\hline $\mathbf{2 7}$ & 92 & 1.51 & 0.0655 & 0.9 & 0.8345 \\
\hline $\mathbf{2 8}$ & 92 & 1.51 & 0.0655 & 0.93 & 0.8645 \\
\hline $\mathbf{2 9}$ & 92 & 1.51 & 0.0655 & 0.96 & 0.8945 \\
\hline $\mathbf{3 0}$ & 96 & 2.05 & 0.0211 & 1 & 0.9789 \\
\hline & & & & & \\
\hline
\end{tabular}

Determining $\mathrm{Z}$ score by using formula as follows:

$Z=\frac{X 1-\bar{X}}{S D}$

$Z=\frac{64-80.8}{7.4}=-2.27$

From computation, it can be concluded that mean score was 80.8 and standard deviation was 7.4. Moreover, based on table2 shows that the $\mathrm{L}_{0}$ score $(0.0698)<\mathrm{L}_{\mathrm{t}}$ (0.161). It indicates that the sample data of experimental group has normal distribution and can be used for research data. (See the value of $L_{0}$ in Muwarni, 2000).

Moreover, by using similar way, the calculation of normality test for control group can be outlined as follows:

Table 3 the Post-test Result of Control Group

\begin{tabular}{ccccccc}
\hline Respondent & $\mathbf{X}$ & $\mathbf{F}$ & $\mathbf{F X}$ & $\mathbf{X 2}$ & $\mathbf{X}^{\mathbf{2}}$ & $\mathbf{F X}^{\mathbf{2}}$ \\
\hline $\mathbf{1}$ & 52 & 1 & 52 & -16.53 & 273.24 & 273.24 \\
\hline $\mathbf{2}$ & 56 & 3 & 168 & -12.53 & 157 & 471 \\
\hline $\mathbf{3}$ & 60 & 6 & 360 & -8.53 & 72.76 & 436.56 \\
\hline $\mathbf{4}$ & 64 & 3 & 192 & -4.53 & 20.52 & 61.56 \\
\hline $\mathbf{5}$ & 68 & 3 & 204 & -0.53 & 0.28 & 0.84 \\
\hline $\mathbf{6}$ & 72 & 4 & 288 & 3.47 & 12.04 & 48.16 \\
\hline $\mathbf{7}$ & 76 & 5 & 380 & 7.47 & 55.8 & 279 \\
\hline $\mathbf{8}$ & 80 & 3 & 240 & 11.47 & 131.56 & 394.68 \\
\hline
\end{tabular}

Vol 1 No 1 Tahun 2021 


\begin{tabular}{ccccccc}
\hline $\mathbf{9}$ & 84 & 1 & 84 & 15.47 & 239.32 & 239.32 \\
\hline $\mathbf{1 0}$ & 88 & 1 & 88 & 19.47 & 379.08 & 379.08 \\
\hline & Total & 30 & 2056 & & & 2583.44 \\
\hline $\boldsymbol{\mu}$ & & 68.53 & & & \\
\hline & SD & & & & & \\
\hline
\end{tabular}

Determining mean of experiment group (X2) by using formula as follows:

$\bar{X}=\frac{\sum F X}{\sum F}$

$\bar{X}=\frac{2056}{30}=68.53$

Counting standard deviation of experiment group (X2) by using formula as follows:

$S D=\sqrt{\frac{\sum F X}{\sum F}}$
$S D=\sqrt{\frac{2583,44}{30}}$
$S D=\sqrt{86.11}=9.27$

Furthermore, the previous data are used to test its normality by using Lilliefors formula as follows:

Table 4 Normality Test of Control Group

\begin{tabular}{cccccc}
\hline $\mathbf{N o}$ & $\mathbf{X 1}$ & $\mathbf{Z}$ & $\mathbf{F}(\mathbf{Z})$ & $\mathbf{S}(\mathbf{Z})$ & $\mathbf{( F}(\mathbf{Z})-\mathbf{S}(\mathbf{Z}))$ \\
\hline $\mathbf{1}$ & 52 & -1.78 & 0.0375 & 0.03 & 0.345 \\
$\mathbf{2}$ & 56 & -1.35 & 0.0885 & 0.06 & 0.0285 \\
\hline $\mathbf{3}$ & 56 & -1.35 & 0.0885 & 0.1 & 0.0115 \\
\hline $\mathbf{4}$ & 56 & -1.35 & 0.0885 & 0.13 & 0.0415 \\
\hline $\mathbf{5}$ & 60 & -0.92 & 0.1788 & 0.16 & 0.0188 \\
\hline $\mathbf{6}$ & 60 & -0.92 & 0.1788 & 0.2 & 0.0212 \\
\hline $\mathbf{7}$ & 60 & -0.92 & 0.1788 & 0.23 & 0.0512 \\
\hline $\mathbf{8}$ & 60 & -0.92 & 0.1788 & 0.26 & 0.0812 \\
\hline $\mathbf{9}$ & 60 & -0.92 & 0.1788 & 0.3 & 0.1212 \\
\hline $\mathbf{1 0}$ & 60 & -0.92 & 0.1788 & 0.33 & 0.1512 \\
\hline $\mathbf{1 1}$ & 64 & -0.48 & 0.3156 & 0.36 & 0.0444 \\
\hline $\mathbf{1 2}$ & 64 & -0.48 & 0.3156 & 0.4 & 0.0844 \\
\hline $\mathbf{1 3}$ & 64 & -0.48 & 0.3156 & 0.43 & 0.1144 \\
\hline $\mathbf{1 4}$ & 68 & -0.05 & 0.4801 & 0.46 & 0.0201 \\
\hline $\mathbf{1 5}$ & 68 & -0.05 & 0.4801 & 0.5 & 0.0199 \\
\hline $\mathbf{1 6}$ & 68 & -0.05 & 0.4801 & 0.53 & 0.0499 \\
\hline $\mathbf{1 7}$ & 72 & 0.37 & 0.3557 & 0.56 & 0.2043 \\
\hline $\mathbf{1 8}$ & 72 & 0.37 & 0.3557 & 0.6 & 0.2443 \\
\hline $\mathbf{1 9}$ & 72 & 0.37 & 0.3557 & 0.63 & 0.2743 \\
\hline $\mathbf{2 0}$ & 72 & 0.37 & 0.3557 & 0.66 & 0.3043 \\
\hline $\mathbf{2 1}$ & 76 & 0.8 & 0.2119 & 0.7 & 0.4881 \\
\hline $\mathbf{2 2}$ & 76 & 0.8 & 0.2119 & 0.73 & 0.5181 \\
\hline $\mathbf{2 3}$ & 76 & 0.8 & 0.2119 & 0.76 & 0.5481 \\
\hline $\mathbf{2 4}$ & 76 & 0.8 & 0.2119 & 0.8 & 0.6181 \\
\hline $\mathbf{2 5}$ & 76 & 0.8 & 0.2119 & 0.86 & 0.7507 \\
\hline $\mathbf{2 6}$ & 80 & 1.23 & 0.1093 & & \\
\hline & & & & 0.83 & \\
\hline
\end{tabular}




\begin{tabular}{llcccc}
\hline $\mathbf{2 7}$ & 80 & 1.23 & 0.1093 & 0.9 & 0.7907 \\
\hline $\mathbf{2 8}$ & 80 & 1.23 & 0.1093 & 0.93 & 0.8207 \\
\hline $\mathbf{2 9}$ & 84 & 1.66 & 0.0485 & 0.96 & 0.9115 \\
\hline $\mathbf{3 0}$ & 88 & 2.1 & 0.0179 & 1 & 0.9821 \\
\hline
\end{tabular}

Determining $\mathrm{Z}$ score by using formula as follows:

$Z=\frac{X 1-\bar{X}}{S D}$

$Z=\frac{52-68.53}{9.27}=-2.27$

From computation above, it can be concluded that mean score was 68.53 and standard deviation was 9.27. Moreover, based table 4 shows that the $\mathrm{L}_{0}$ score $(0.0499)<$ $\mathrm{L}_{\mathrm{t}}(0.161)$. It indicates that the sample data of control group has normal distribution and can be used for research data.

After doing normality test, then the I will do t-test to examine whether folktale has a significant effect to enhance students' listening comprehension on narrative story. The below table illustrates the calculation score from both groups.

Table 5 The Calculation Score of Experimental and Control Group

\begin{tabular}{|c|c|c|c|c|c|c|}
\hline No & X1 & X2 & $\mathrm{X} 1$ & $\mathrm{X} 2$ & $\mathrm{X}_{1}{ }^{2}$ & $\mathrm{X}_{2}^{2}$ \\
\hline 1 & 72 & 52 & -8.8 & -16.53 & 77.44 & 273.24 \\
\hline 2 & 76 & 56 & -4.8 & -12.53 & 23.04 & 157,09 \\
\hline 3 & 80 & 60 & -0.8 & -8.53 & 0.64 & 72.76 \\
\hline 4 & 68 & 88 & 7.2 & 19.47 & 51.84 & 379.08 \\
\hline 5 & 84 & 60 & 3.2 & -8.53 & 10.24 & 72.76 \\
\hline 6 & 84 & 68 & 3.2 & -0.53 & 10.24 & 0.28 \\
\hline 7 & 64 & 72 & -16.8 & 3.47 & 282.24 & 12.04 \\
\hline 8 & 80 & 60 & -0.8 & -8.53 & 0.64 & 72.76 \\
\hline 9 & 80 & 56 & -0.8 & -12.53 & 0.64 & 157,09 \\
\hline 10 & 76 & 60 & -4.8 & -8.53 & 23.04 & 72.76 \\
\hline 11 & 88 & 64 & 7.2 & -4.53 & 51.84 & 20.52 \\
\hline 12 & 80 & 76 & -0.8 & 7.47 & 0.64 & 55.8 \\
\hline 13 & 84 & 76 & 3.2 & 7.47 & 10.24 & 55.8 \\
\hline 14 & 96 & 72 & 15.2 & 3.47 & 231.04 & 12.04 \\
\hline 15 & 92 & 80 & 11.2 & 11.47 & 125.44 & 131.56 \\
\hline 16 & 76 & 72 & -4.8 & 3.47 & 23.04 & 12.04 \\
\hline 17 & 80 & 72 & -0.8 & 3.47 & 0.64 & 12.04 \\
\hline 18 & 76 & 56 & -4.8 & -12.53 & 23.04 & 157,09 \\
\hline 19 & 84 & 60 & 3.2 & -8.53 & 10.24 & 72.76 \\
\hline 20 & 88 & 60 & 7.2 & -8.53 & 51.84 & 72.76 \\
\hline 21 & 72 & 64 & -8.8 & -4.53 & 77.44 & 20.52 \\
\hline 22 & 76 & 68 & -4.8 & -0.53 & 23.04 & 0.28 \\
\hline 23 & 80 & 76 & -0.8 & 7.47 & 0.64 & 55.8 \\
\hline 24 & 84 & 84 & 3.2 & 15.47 & 10.24 & 239.32 \\
\hline 25 & 92 & 80 & 11.2 & 11.47 & 125.44 & 131.56 \\
\hline 26 & 92 & 76 & 11.2 & 7.47 & 125.44 & 55.8 \\
\hline 27 & 84 & 68 & 3.2 & -0.53 & 10.24 & 0.28 \\
\hline 28 & 88 & 76 & 7.2 & 7.47 & 51.84 & 55.8 \\
\hline 29 & 72 & 80 & -8.8 & 11.47 & 77.44 & 131.56 \\
\hline \multirow[t]{2}{*}{30} & 76 & 64 & -4.8 & -4.53 & 23.04 & 20.52 \\
\hline & $\Sigma X 1=2424$ & $\Sigma X 2=2056$ & $\Sigma \mathrm{X}_{1}=0$ & $\Sigma \mathrm{X}_{2}=0$ & $\Sigma \mathrm{X}_{1}^{2}=1532.8$ & $\Sigma \mathrm{X}_{2}^{2}=2583.71$ \\
\hline
\end{tabular}


From the table above, the writer obtained data as follows $\Sigma \mathrm{X} 1=2424, \Sigma \mathrm{X} 2=$ 2056, $\Sigma \mathrm{X}_{1}{ }^{2}=1532.8$, and $\Sigma \mathrm{X}_{2}{ }^{2}=2583.71$. Moreover, the writer compare the result of post-test from both group by using t-test formula as follows:

$$
\begin{aligned}
& t_{0}=\frac{M_{1}-M_{2}}{\sqrt{\left\{\frac{\sum X_{1}^{2}+\sum X_{2}^{2}}{N_{2}+N_{2}-2}\right\}\left\{\frac{N_{1}+N_{2}}{N_{1} \cdot N_{2}}\right\}}} \\
& t_{0}=\frac{80.8-68.53}{\sqrt{\left\{\frac{1532.8+2583.71}{30+30-2}\right\}\left\{\frac{30+30}{30.30}\right\}}} \\
& t_{0}=\frac{12.27}{\sqrt{\{70.97\} 0.06\}}} \\
& t_{0}=\frac{12.27}{\sqrt{4.25}} \\
& t_{0}=\frac{12.27}{2.06}=5.96
\end{aligned}
$$

After doing t-test, I compared $t_{0}$ with $t_{t}$ on degree of significance $5 \%$ that is 1.67 . So, the result of t-test shows that $t_{t}>t_{0}$ or $5.96>1.67$. In brief, it can be inferred that $\mathrm{H}_{\mathrm{a}}$ (alternative hypothesis) is accepted. Meanwhile, $\mathrm{H}_{0}$ (null hypothesis) is rejected. In other words, we can draw a conclusion that there is a significant effect of using folktale in enhancing students' listening comprehension on narrative story.

Besides, the success of experimental study is also determined by giving appropriate treatments for experimental group. In designing treatments, I in collaboration with the English teacher tried to select familiar folktales which have good moral values for students. some local folktale such as the legend of Tangkuban Perahu, Roro Jongrang, the Origin of Lake Toba, the story of Jaka Tarub, and Malin Kundang were chosen because they have interesting plot of story, easy to understand, and help develop attitude towards the foreign language learning. In addition, based on my observation, the use of folktale in learning listening also allows teacher to introduce or revise new vocabularies and sentence structures by exposing students to language in varied, memorable, and familiar context which will enrich their thinking and gradually enter their own speech.

In practice, there are a number of practical tips of listening can be used to make learning activities more enjoyable and successful for students (Garvie, 1990), they are:

a) If they are unfamiliar with certain folktale, teacher can describe the synopsis of story in beginning of lesson,

b) If possible, have students sit on the floor around teacher when they listen folktale story, teacher must make sure every student can listen story clearly,

c) Play video slowly and clearly, give students time to think, ask questions, look at the pictures, and make comments,

d) Don't worry to pause or repeat the video, it allows students to memorize story and activate their prior knowledge, 
e) Teacher can encourage students to take part in story by repeating key vocabularies items and phrases,

f) To make story more real and impressive, teacher can use gesture, mime, facial expressions, varied pace and tone.

g) Practice and exposure students to listen folktales as many as possible.

In addition, I and the English teacher also discussed some best practices of teaching listening and designed listening assignments to improve the quality of teaching and learning processes. The sequences of listening in treatment phases are as follows:

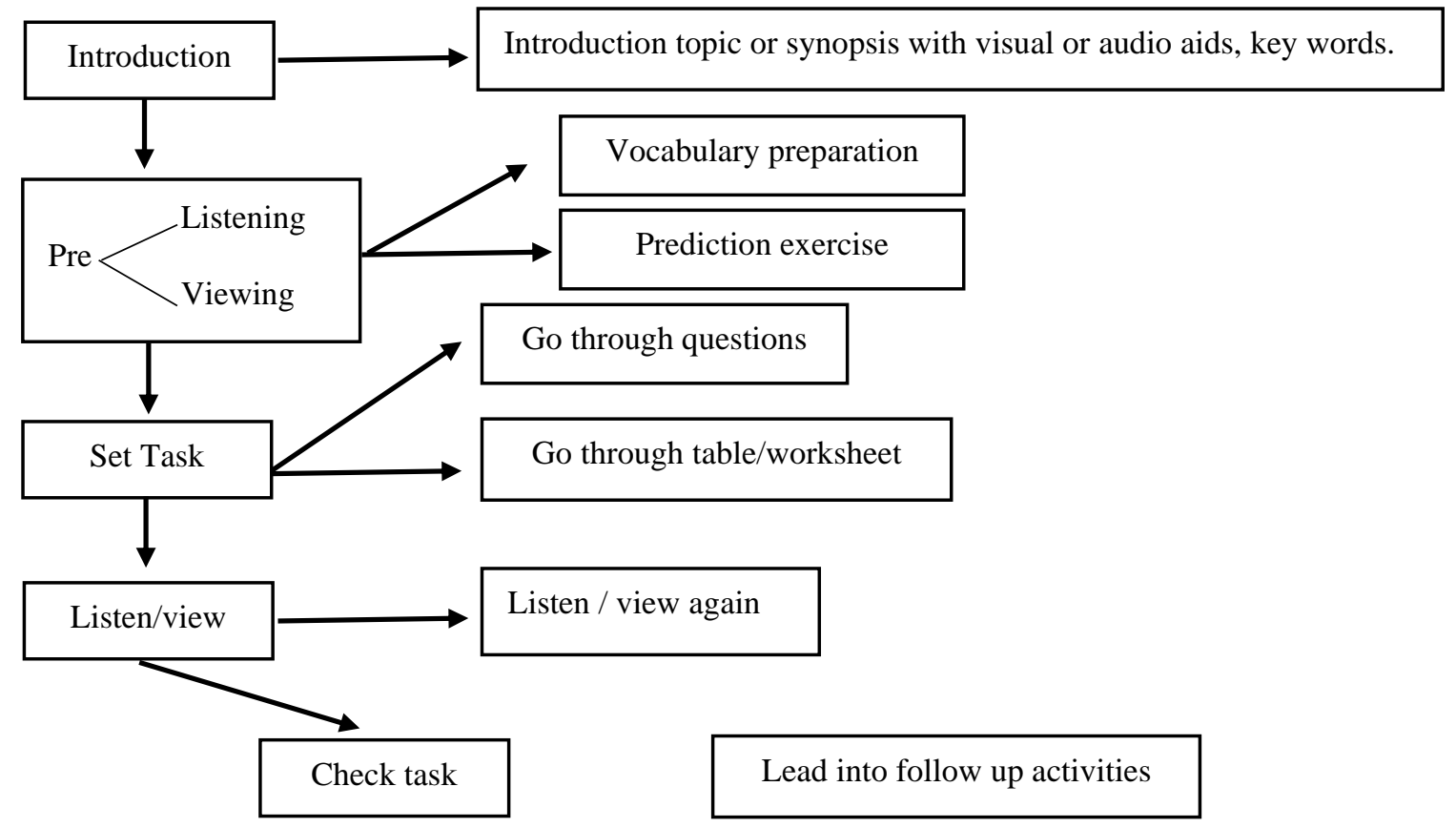

Picture 1 Good Sequence of Listening (Jack C Richard, 2008)

Finally, the findings of this study proved that folktale has a significant effect to improve students' listening comprehension on narrative story and make teaching and learning processes of listening more enjoyable and effective as well as build up students' confidence and develop their listening skills.

\section{CONCLUSIONS}

Having analyzed the data statistically and interpreted the teaching and learning processes of listening thoroughly, this study comes to several conclusion that listening is often neglected by some English teachers because productive skills often valued better than receptive skills. Moreover, to overcome students' problems in listening on narrative story, I proposed folktale to the English teacher. Because plot of story of folktale is easy to understand and able to develop students' language proficiencies. In addition, the final results of this study statistically proved that folktale has a significant effect to improve students' listening comprehension on narrative story. It reflects on the result of t-test which showed that $t_{t}>t_{0}$ or $5.96>1.67$. 


\section{REFERENCES}

Anderson. Mark and Kathy Anderson. 1997. Text Types in English. Chappel Street: MacMillan Education Australia PTY Ltd.

Brown, Ellen and Bruce Rosenberg. 1998. Encyclopedia of Folklore and Literature, California: ABC-Clio, Inc.

Brown, James and Theodore S Rodgers. 2003. Doing Second Research, Beijing: Oxford University Press.

Brown, Steven. 2006. Teaching Listening, New York: Cambridge University Press.

David, Herman. 2007. Narrative, New York: Cambridge University Press.

Ellis, Gail and Jean Brewster. 1991. the Story Telling Handbook for Primary Teacher, London: Penguin Books.

Flowerdew, John and Lindsay Miller. 2005. Second Language Listening, New York: Cambridge University Press.

Frankel, Jack R. and Norman E. Wallen. 2007. How to design and evaluate research in education. $6^{\text {th }}$ edition: Singapore: McGraw Hill.

Garvie, Edie. 1990. Story as Vehicle, Bristol: Multilingual Matters Ltd.

Nunan, David. 2000. Language Teaching Methodology, Kuala Lumpur: Longman.

Nunan, David. 2000. Research Methods in Language Learning, New York: Cambridge University Press.

Richard, Jack C. 2008. Teaching Listening and Speaking: from Theory to Practice, New York: Cambridge University Press.

Richard, Jack and Willy Renandya. 2000. Methodology in Language Learning, New York: Cambridge University Press.

Simpson, Jacqueline, and Steve Roud. 2000. a Dictionary of English Folklore, New York: Oxford University Press.

Syah, Darwian, et al,. 2006. Pengantar Statistik. Jakarta: UIN Jakarta Press. 